\title{
Policies, Political-Economy, and Swidden in Southeast Asia
}

\author{
Jefferson Fox • Yayoi Fujita • Dimbab Ngidang • \\ Nancy Peluso • Lesley Potter • Niken Sakuntaladewi • \\ Janet Sturgeon • David Thomas
}

Published online: 19 May 2009

(C) The Author(s) 2009. This article is published with open access at Springerlink.com

\begin{abstract}
For centuries swidden was an important farming practice found across the girth of Southeast Asia. Today, however, these systems are changing and sometimes disappearing at a pace never before experienced. In order to explain the demise or transitioning of swidden we need to understand the rapid and massive changes that have and are occurring in the political and economic environment in which these farmers operate. Swidden farming has always been characterized by change, but since the onset of modern independent nation states, governments and markets in Southeast Asia have transformed the terms of swiddeners' everyday lives to a degree that is significantly different from that ever experienced before. In this paper we identified six factors that have contributed to the demise or transformation of swidden systems, and support these arguments with examples from China (Xishuangbanna), Laos, Thailand, Malaysia, and Indonesia. These trends include classifying swiddeners as ethnic minorities within nation-states, dividing the landscape into forest and perma-
\end{abstract}

J. Fox $(\bowtie)$

East-West Center,

Honolulu, HI, USA

e-mail: FoxJ@EastWestCenter.org

Y. Fujita

Department of Anthropology, University of Chicago,

Chicago, IL, USA

e-mail: yayoi@uchicago.edu

D. Ngidang

Faculty of Social Science, University Malaysia Sarawak,

Sarawak, Malaysia

e-mail:dimbab@ieas.unimas.edu

N. Peluso

Department of Environmental Science, Policy, and Management,

University of California, Berkeley,

Berkeley, CA, USA

e-mail: npeluso@nature.berkeley.edu nent agriculture, expansion of forest departments and the rise of conservation, resettlement, privatization and commoditization of land and land-based production, and expansion of market infrastructure and the promotion of industrial agriculture. In addition we note a growing trend toward a transition from rural to urban livelihoods and expanding urban-labor markets.

Keywords Policies $\cdot$ Political economy Political ecology Swidden $\cdot$ Southeast Asia

Swidden farmers throughout Southeast Asia are rapidly transforming or abandoning traditional land-use practices (Padoch et al. 2007). In order to explain the demise of swidden we need to understand the political and economic changes that have occurred across the region, affecting the contexts in which these farmers operate. Of course, change has always characterized the milieu within which swiddeners function, and the intensities and rapidity of change in

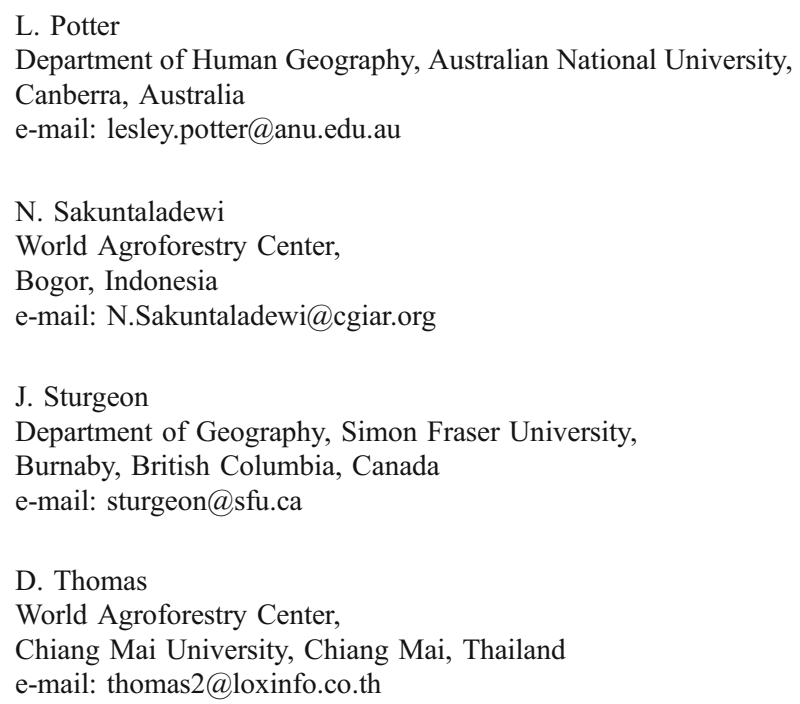






Fig. 1 Location of case studies in Southeast Asia

the political-economic contexts of swiddeners' everyday lives were particularly significant during the colonial era (Wolf 1982; Anderson 1991; Scott 1976; Thongchai 1994). However, since World War II, swiddeners' everyday lives have been transformed to a greater degree. The ways in which national policies and development practices have affected swiddeners and swidden cultivation, and the ways swiddeners have responded or contributed to these political economic transitions of the last half-century, need to be understood in the context of broader political-economic and political-ecological transitions.

We discuss six trends we contend have affected the practice of swidden agriculture in Southeast Asia and support these arguments with examples from China (Xishuangbanna), Laos, Thailand, Malaysia, and Indonesia (Fig. 1). These trends include: (1) classifying swiddeners as ethnic minorities within nation-states; (2) dividing the landscape into forest and permanent agriculture; (3) expansion of forest departments and the rise of conserva- tion; (4) resettlement; (5) privatization and commoditization of land and land-based production; and (6) expansion of markets, roads, and other infrastructure and the promotion of industrial agriculture. In addition we note a growing trend toward a transition from rural to urban livelihoods and expanding urban-labor markets. These trends are not arranged in order of importance.

There are exceptions to the ways in which these largescale influences have played out across space and time in the region-including how and when they have been resisted, thwarted, or modified - but it is indisputable that they have caused a decline in the practice of extensive forms of swidden agriculture. These forces have articulated with other large-scale processes such as the rise and integration of policies and practices associated with the spread of capitalist production and trade, scientific and bureaucratic land management, government by nationstates, the involvement of non-government organizations of many types in environmental governance, and urbani- 
zation. We contend also that the serial emergence of forestry and conservation for development, the promotion of large-scale state or corporate-controlled industrial agriculture (as a means of both resource stabilization and state accumulation), and other discourses of development have affected swidden agriculture in a multitude of ways, sometimes positively for its practitioners, but often to their detriment.

In this essay, we explain why the practice of swidden cultivation has been declining in Southeast Asia and how states and other international actors have contributed to this trend. The intent is not to suggest a relentless and unopposed steamroller of anti-swidden policies and practices emanating from international and national state institutions, but rather to suggest that swiddeners in different nation-states of the region are being affected by similar policies and forces. When, and under what specific historical and geographic conditions, these policies and programs have interacted with other socio-economic and cultural forces varies. The paper is closely related to the following article in this special issue by Cramb et al. on the implications of the demise and transformation of swiddening for people's livelihoods.

\section{Classifying Swiddeners as Ethnic Minorities Within Nation-States}

Since WWII and the rise of nation-states in Southeast Asia and elsewhere, swiddeners have been classified as ethnic minorities. Many of the region's peoples from lowland or settled agricultural societies control national governments and constitute ethnic majorities in "national" population counts. This does not mean that all minorities are swiddeners, but rather that most swiddeners are minorities. Examples include Dayaks in Indonesian and Malaysian provinces of Borneo; Orang Asli in Peninsular Malaysia; Akha, H'mong, Lisu, Khmu and others in southwest China and mainland Southeast Asia; and Bataks and Tagbanua in the Philippines. National scale resettlement programs that bring lowlanders into swiddeners' former territories may also make the latter into minorities in their own regional homelands.

National-level ethnic minorities are often treated in ways that make them out to be backward and in need of "help" from both more modern nation-states and development projects (e.g., Li 2007, Denton 1997, Tsing 1993, and Dove 1988). In China, Vietnam, and Laos, the official view of shifting cultivation was influenced by a Marxist/Stalinist view that swiddening represents a primitive "stage" in a social evolutionary perspective that associated modes of production with ethnicity (Jamieson 1991, Rambo 1995, Sturgeon 2005, Cramb et al. 2009).
As we show in the second half of this paper, national states have increasingly asserted control over swidden lands and the people who farm them, often completely or partially dispossessing the peoples who depend on them. Only recently, for example, has the Thai government begun to recognize the citizenship rights of ethnic minorities who live in upland areas and practice swidden agriculture. Even today many people are officially assigned "mountain minority" identity status, under which their movement and access to government programs and land are restricted. While such intermediate status provides access to some social services, all those with less than full citizenship have no voice or representation in political systems, and are constantly subject to paying often heavy "transaction costs" to "stay out of trouble" (Thomas et al. 2008, Sturgeon 2005). Some of the long-standing modes of struggle between lowland and upland groups, the primitivizing of upland groups by lowland groups and state agencies, and the misunderstandings and conflicts over the resources used by upland groups remain problematic. In many cases, these beliefs aggravate and animate the policies and practices of Southeast Asia state actors and corporate entrepreneurs in areas that once were or still are occupied by swiddeners.

Thailand may be an extreme case, but across the region official demonization of swidden agriculture is often conflated with negative assessments of the ethnic minorities who practice it. The translations of these assessments into policy documents, laws, practices, and attitudes have ranged from the tagging of swidden cultivators as "lower quality people" in Southwest China to "isolated backward populations" in Indonesia (Li 1999). The use of such terms and ideas render swidden agriculture not only a primitive practice, but articulate with the treatment of swidden cultivators as primitive peoples - a concept that can be turned to advantage in some cases (Tsing 1999), but generally works against an understanding of swidden cultivation on its own terms (Li 1999; Scott 1998).

\section{Division of the Landscape into Forest and Permanent Agriculture}

A second trend related to the political economic marginalization of swiddeners is that land policies and laws governing access to and control of land both limit areas where swidden agriculture can expand and take away existing swidden fallows. Many countries in the region have laws that criminalize swidden cultivation (Peluso and Vandergeest 2001). Many of these laws have been on the books for a century or more. In the Philippines the Forest Regulation of 1873 contained a clause banning caingin (the term for swidden); and in Indonesia, swidden cultivation was prohibited by ordinance in 1874 and villagers were 
required to obtain official permission before clearing forest to extend village agriculture (Potter 2003: 37-8, Li 2007:39). In the past many of these laws were not or could not be enforced. Sometimes local government officials were sympathetic with swiddeners and did not enforce these laws, knowing that no viable alternative land-use practices or alternative income sources existed for them; people had few other livelihood choices (e.g. De Haan 1929, for South and East Borneo). Today, with the development of roads and market infrastructure and the expansion of capitalism through the farthest reaches of the region, alternatives exist. New permanent land uses and zonings are insisted upon by governments, pushing swidden farmers out by laws and policies that criminalize swidden agriculture and alternative land-use options; at the same time urban and rural wagelabor opportunities are pulling swidden farmers - or at least some members of their households - away from agricultural livelihoods (Fox 2000; Rigg 2006).

Swiddening is an agroforestry system; it is neither agriculture nor forestry but a comprehensive landscape management system that operates on a timescale that cannot be captured by a snapshot of a forest or field. Understanding swidden requires a long-term view of the changing agrarian environment. Different types of field crops and tree species occupy a single plot of land, changing over time. The development of professional forestry and the division of rural landscapes between "forests" and "agricultural lands" artificially split swidden landscapes between forest and agriculture institutions (Agrawal and Sivaramakrishnan 2001). This division between forests and agricultural lands has worked against the practice and understanding of swidden (Peluso and Vandergeest 2001; van Noordwijk et al. 2008). The division was made generally without serious consideration of what would or should happen to the largest physical portion of swidden agroforestry farms - the fallows. With fallows ranging from heavily managed clusters of economic trees and food crops to minimally managed secondary forest, they pose a dilemma to government agencies trying to classify them as forest "in the making" or agriculture "in transition".

Most Southeast Asian national governments do not recognize swidden fallows as part of the agricultural landscape but rather classify fallows as forests (perhaps "degraded") or "abandoned" land. Some countries (e.g., China, Vietnam) allow private individuals to manage forest lands (usually as long-term leaseholders rather than private landowners). Others (e.g., Thailand) do not legally allow smallholders to own or manage forest land at all or only minimally. Some countries (e.g., Vietnam) allow smallholders to manage land zoned as forests, but revoke this right if smallholders use the forest for swidden (1991 Forest Law, Decree $02 / \mathrm{CP}$ ). The inability legally to access fallows classified by the state as forests forces farmers to either illegally reopen their fallow fields or to practice permanent cultivation. Land laws that restrict the use of land to either permanent agriculture or forestry also deny swiddeners the opportunity to take part in decisions about land-use transformations of these lands.

\section{The Expansion of Forest Departments and the Rise of Conservation}

Related to the division of agrarian environments into forests and agriculture, the expansion of forest departments and the rise and expansion of conservation organizations have also affected swidden cultivation in Southeast Asia. More territory across the region has been reserved or gazetted as national or "political" forest since the end of WWII than ever before, although some parts of the region had large forestry departments during the colonial period (e.g., Java, Malaya, Vietnam). Peluso and Vandergeest (2001) showed that Java and the Federated Malay States reserved significant areas of land as state forest during the colonial period in what are today parts of the countries of Indonesia and Malaysia. In contrast, colonial-era Sarawak, Siam, and Kalimantan had minuscule percentages of their land areas reserved (see also, Potter 2003).

Forestry's role as a key player in the bureaucracies of new nation-states was positively influenced by the post WWII boom in timber demand and the rise of international timber markets; in some places forestry became one of the most powerful ministries. In the Philippines, for example, 55\% of the country's total land area is managed under the authority of the Forest Management Bureau; in Thailand the Royal Forest Department today administers $40 \%$ of the nation's land area; and in Indonesia, approximately $70 \%$ of the nation's land is under the Ministry of Forestry (Poffenberger 1990: 7-8, McCarthy 2006). Post-colonial forest management authorities in these countries oversaw the massive expansion of national production and protection forests, the implementation of fast-growing timber and pulp plantations, development of industrial forestry policies, and in concert with these new land uses, the wide-spread criminalization of swidden cultivation (see, Vandergeest and Peluso 2006; Majid-Cooke 2006; Ngidang 2002; Ross 2001; Dauvergne 1997).

The incursion of national states into swiddeners' active farm plots and forest fallows, and the states' claims to forests led to a great deal of degradation as well as controversy over legal and illegal logging and the conversion of forests to monoculturally produced estate crops. More importantly, the blame for degradation was largely directed at swiddeners, rather than at the loggers and industrial forestry developers (pulp and paper) who cut, cleared, and degraded the forests extensively. Scholarly accounts have repeatedly shown that 
greater degradation was caused by these industries than by swiddeners (Thapa and Weber 1991; Thiesenhausen 1991) but most national policy-makers and international practitioners have continued to publically blame swiddeners (see also, cites on fires: Dennis et al. 2005; Brookfield et al. 1995:172; Rigg 2003:298).

The rise of conservation, particularly after the $1980 \mathrm{~s}$, created new state and international controls on forests (in law and policy, at least) for conservation and nature preservation. Again, these ideas were not technically new; there were protection forests under colonialism in Java and nature monuments or nature reserves, or even calls for protecting certain species such as birds of paradise (Boomgaard 2005; Cribb 1997; Grove 1995; Peluso 1992). However, two things have been different since the 1980s.

First, the rise of institutionalized conservation funded by wealthy, Northern-based interests, benefited from and contributed incentives to the implementation of authoritarian national policies in the capitalist economies of Malaysia, Indonesia, Thailand, and the Philippines, and later, in transitional economies of Vietnam, China, and Laos. To this end, for example, national parks were forcibly enacted on lands that were formerly the swidden fields and fallows of local people in northern Thailand (e.g., Doi Inthanons, Doi Suthep), Indonesia (e.g., Kerinci Seblat, Kutai, Gunung Rinjani, etc.), and Malaysia (e.g., Mount Kinabalu, Mulu, Loagan Bunut, etc.(see Ngidang 2005; Liam 2005). In the socialist states of China, Vietnam, and Laos, the top-down nature of government authority led to conservation gaining ground in policy and law, where nature reserves and national parks were imposed (Long et al. 1999). However, in all of these places, the extreme territorial exclusions imposed by or desired by "big conservation" interests could neither be realized in their entirety nor were they entirely supported by everyone in government, international development agencies or local NGOs. In the early years of conservation's rise in the region, China, for example, was reluctant to take away people's sources of welfare and implemented different sorts of policies for governing and limiting access to forests (Sturgeon 2005; Menzies 1994; Grinspoon 2002). In Laos, Indonesia, and elsewhere the state often lacked the budget and people necessary to enforce protected areas on the ground; the task was made more difficult when members of the military were implicated in the theft of timber and other products from within protected areas (Obidzinski et al. 2007; McCarthy 2006; Peluso 1993).

Second, these particular trends were further exacerbated by the region's geographies of power alluded to above: people from lowland-based, wet rice growing societies tended to rise to government power while minorities in the uplands were increasingly the sole occupants of areas with remaining forest cover (Li 1999; Vandergeest 2003; Belsky
2008). Both sets of groups had different but unequal sorts of power-the former had the power of law, policy, and states backed by military and police power, the latter the power of presence in uplands distant from the seats of government and the related ability in some cases to resist and contest the claims of the national states and international conservationists. The growing ability of the state to police boundaries and to enforce policies, however, has made it increasingly difficult for upland swidden farmers to resist. In a paradoxical manner, as well, the emphasis on community forestry as a way of protecting upland people's rights has had the effect Walker called "arborealization" of the uplands - an emphasis on tree-growing practices to the detriment of field agriculture or field cycles in swidden agriculture (Walker 2004). This affects the capacity of swidden cultivators to grow their own food as less land is available for agriculture, and also has effects on internal differentiation and the livelihoods possible from tree plantations as farmers able to expand or consolidate land holdings under trees may acquire even more capital to expand their landholdings further.

\section{Resettlement}

Resettlement is another regional trend affecting the practice of swidden cultivation. This takes various forms: swiddeners may be moved out of the uplands (see case study from Laos) or out of forests or away from international borders. Or, lowland peoples might be moved into the uplands, into swiddeners' territories, as it were (Elmhirst 1999; Uhlig 1984; Vargas 1985; Hardy 2003; Peluso and Vandergeest 2009). The reasons for the latter policies and practices were varied and related to other trends. Many governments had long wanted swiddeners to settle down and practice sedentary agriculture (Wadley 2003; Wadley and Eilenberg 2005; Potter et al. 1995; Vargas 1985; Dove 1983). Government agents sometimes claimed that farmers resettled from lowlands could serve as examples to swiddeners, showing them "how to do settled agriculture." Of course, where there is not enough water for irrigation or the soils are unsuitable, these upland environments cannot support the kinds of settled agricultural systems one finds in more fertile and well-watered lowland environments or in hill areas endowed with deep volcanic soils. Research has shown, time and again, that many upland environments are unsuited to repeated annual cultivation of field crops on the same plots of land (Dennis and Colfer 2006; Chokkalingam et al. 2005).

A second reason that lowland people have been resettled in uplands is to relieve poverty and population pressure on land in densely populated and land-poor lowland parts of the country. The transmigration projects of Indonesia, the 
resettlements in Vietnam, and the opening of roads to encourage agricultural colonization and development in the Philippines and Thailand are all examples of this form of national scale "agrarian reform." As has been amply shown by the critical literature on transmigration in Indonesia, these projects often cause more forest to be cut down in a single swoop than swiddening, whether in the preparation stage or by the colonists themselves, causing rapid degradation (Rich 1995; Elmhirst 1999). If projects include the construction of roads (which most do) there is more intense (and longer term) degradation associated with roads than with swidden, including the "following" of logging roads by second and third waves of swiddeners and spontaneous migrants (Brookfield et al. 1995). If they do not include the construction of appropriate roads, transmigrants in converted forest areas often fail because they do not have sufficient access to markets. They are also often in trouble because they are required to do permanent agriculture for their food crops in addition to the cultivation of tree crops in a number of plantation-based land management systems. As mentioned above, upland soils are often unsuited to continuous cultivation of field crops. Thus it was also widely documented in Kalimantan that transmigrants were often displaced by the very conditions of their transmigration projects and subsequently learned to swidden from local people (Hidayati 1994; Abdullah 1996).

Sometimes resettlement goes "downhill" and swiddeners are resettled out of upland areas and away from forests and borders. In such cases, swiddeners may have been dispossessed because their lands were appropriated by state agencies for the resettlement of lowland peoples (e.g., Indonesia, Philippines). This was a common counterinsurgency strategy in Malaya, Sarawak, Kalimantan, and Thailand in the Cold War era of regional insurgencies (Peluso and Vandergeest 2009; Sioh 2004; Osborne 1965). The swiddeners may be permitted to move slowly, over a period of years, which might make it easier for them to adapt to new circumstances, especially if they are provided with new land. In some cases, governments or projects set compensation rates, although people invariably complain these are extremely low and their land and trees undervalued. Many times, people never receive compensation because of corruption at some level of government (Zaman 2002). In the "Grain for Green" program in China, people were to be compensated for letting their agricultural land be planted in trees and subsequently moved from the jurisdiction of agriculture to forestry. However, many villagers complained they were not compensated for all or even part of the eight years they were supposed to be, and they were simply dispossessed of much of their land while remaining in place (see case on Xishuangbanna below).

\section{The Privatization and Commoditization of Land and Land-Based Production}

The political-economic marginalization of swiddeners has been significantly affected by the extension of capitalist relations and changes in capitalism itself that have driven the privatization of land and increased the amount of commercial agriculture and industrial tree-farming by corporate and government groups, entrepreneurial farmers, and smallholders. This is perhaps the most basic factor affecting the availability of land for swidden, particularly on land that has not been locked up in political forests and protected areas (e.g., Brookfield et al. 1995; Colchester et al. 2006; Brown 2003). The ability to formally privatize land (i.e., not just to enclose it for capitalist production) is a result of the establishment and implementation of national laws and policies that recognize and enforce Western-style, state-authorized, private property rights at the expense of communal and plural systems of tenure. These laws affect the recognition of private property ownership and allow state authority to supersede local authorities.

In Indonesia, for example, the Basic Agrarian Law of 1960 had provisions to recognize customary land rights but key implementing regulations were left ambiguous. Under the 1967 Forestry Law, the Forest Department claimed jurisdiction over a large portion of the nation's total land mass and recognized customary land holdings only when they did not conflict with the department's objectives and regulations (Moniaga 1993). The revised Forestry Law, No 41 of 1999 , has been equally ambivalent about customary rights. It ruled that indigenous people could "manage forest according to the prevailing adat (customary) law" (Chapter IX, Art.67) and suggested that a Government Regulation would be issued to clarify the position, but this has not yet happened. Under the Law, severe sanctions exist against individuals who burn forests, thus proscribing (though not preventing) swidden practices [Art. 50 (3) d; Art.78 (4)].

Laws such as these provided Indonesian administrators with the ability to dispossess people and move them at will. Li (2007) in her study of Central Sulawesi, Indonesia, cited one study that found "land allocated to large-scale plantations was 1.2 million hectares; land allocated to timber concessions and industrial timber plantations was 2.2 million hectares; land under protected forests and wildlife reserves was 2.5 million hectares; and land granted as mining concessions was 1.1 million hectares. Thus the total 'state' land officially allocated was 7 million hectares, although the total land area in the province is only 6.8 million hectares (Li 2007:99). Stories similar to this have been told about Indonesian forestry for years (see Manning 1971; Barber and Churchill 1987; Moniaga 1993). In a similar study of Ratanakiri Province in Cambodia, Butterfield (1997) found that $130 \%$ of the province's land area has either 
been granted as concessions or placed in protected status. Conflicting government allocations like these make no concession to the claims and rights of people living in these areas long before modern states even existed.

Smallholders are also interested in making private claims to land. In her narrative of how the swidden lands of farmers in the hills of Sulawesi became private property, Li (2007) argues that until the 1970s absolute landlessness was unknown because farmers without paddy could access forest land on hillsides to use for swidden. In the 1970s and '80s, the Forest Department openly took over this land and allocated forests to timber corporations for logging, or designated them conservation areas (or protection forests). The closing of the local forest frontier created the conditions for a landless class to emerge. A second phase arose in the 1990s as upland farmers began to plant cacao on the land they had previously used for swiddens. By planting a perennial, long-living tree crop, they effectively excluded the kin and neighbors who had shared customary rights to use this land on a seasonal basis (see also Cramb et al., this issue). Once farmers planted their former swiddens with cacao, they treated both the cacao and the land as private, individual commodities that could be readily sold.

Though new regulations were setting the terms for private property registration, recognition, and transfer, many informal arrangements emerged as well. In Sulawesi, for example, farmers could sell undocumented lands by arguing that their labor invested in land improvements created enduring rights. Officials responsible for land affairs sometimes recognized this principle by issuing an official letter witnessed and stamped by sub-district heads (Li 2007). By making these transactions official (though illegally), district officials effectively acknowledged the customary rights of the land seller. Villagers in Riau province could obtain "land certificates" by paying a fee to both the village head and sub-district chief (Potter and Badcock 2004). These certificates enabled them to sell their land to incoming migrants, though both buyers and sellers recognized that such certificates did not constitute legal title, and that they could be easily ignored or circumvented when more powerful claimants appeared. This suggests one reason for selling land: "insecure tenure increased the temptation for highlanders to sell their land while they could, before a more powerful party took it from them" (Li 2007: 104). Stories of such informal or emergent land markets where none existed previously abound across the region (e.g., Vandergeest 2003; Menzies 1994).

The socialist countries, China, Vietnam, and Laos, passed through a period of collectivization. The political and economic history of these countries of course differs from those without a socialist history, but they also differ amongst themselves in the timing and ways in which they opened their economies to world markets and provided long-term private usufruct rights to natural resources, especially land (Xu et al. 2005; Thongmanivong et al. 2005). It is notable that today all these socialist countries provide stronger private usufruct rights to upland farmers for agricultural and forest lands than do the capitalist countries of Thailand, Malaysia, the Philippines, and Indonesia, though this does not mean that farmers can legally use these lands for swiddening (Rigg 2003).

\section{Expansion of Market Infrastructure and the Promotion of Industrial Agriculture}

Another effect of the spread of capitalist markets, institutions, and policies has been the expansion of market infrastructure and market opportunities and the promotion of industrial agriculture. State policies have supported markets and facilitated corporate and large scale private accumulation of capital through the expansion and upgrading of road, electricity, and telecommunication networks, and in providing tax breaks and other subsidies for investors in capitalist development (Glassman 2006, Harvey 2003). These changes have played major roles in the demise of swidden agriculture. Thomas et al. (2008) suggests that in Thailand the state had two primary objectives when it developed road networks across lands occupied by swidden farmers. These were to maintain national security near its borders with Laos and Myanmar, and to promote opium crop substitution programs. Roads, however, begat roads. The development of this infrastructure facilitated the emergence of smaller roads and new district or local marketplaces, and subsequently enabled the sale of more products from and to these interior areas.

The decline of swidden was not due simply to the introduction of "cash crops"; swiddeners were not new to commodity production: they had been collecting, producing, managing, and selling forest products (e.g., rattan, damar, and bird's nests) and growing pepper, gambir, fruit, coconut and rubber for a century or more. Swidden declined with the introduction of certain crops and their production under certain farming regimes. In the so-called Golden Triangle (Thailand, Laos, and Myanmar) government officials and international planners had been (and still are) concerned about swidden farmers growing opium in their swidden fields - even though some officials were players and partners in the opium trade. These concerns led to the implementation of various opium replacement policies and programs, beginning in the 1960s and continuing until today, as discussed in greater detail below.

Despite these challenges, international investment, expanded markets, and privatization policies have had another effect on swidden. The insertion into the landscape 
of major tracts of industrial agriculture by both smallholders and corporate investors is a large and significant trend in the region. Farmers have been encouraged, enrolled, or seen opportunities to convert their land to commercial crops. Industrial agriculture has long-term effects on the land (see ecology articles in this issue). The most widely grown commodities include oil palm especially in Indonesia and Malaysia, industrial rubber in the entire region; and coffee and tea (particularly in Indonesia, Vietnam, Thailand, and Southern China).

Much industrial agriculture involves schemes for entrepreneurs, corporations or governments to gain control of swidden land. These range from outright dispossession of swiddeners to supposed "joint ventures" with corporate agricultural companies that take control of villagers' customary lands for a period of time as discussed in the case study from Sarawak below (see also Ngidang 1997 , 2002; Majid-Cooke 2003, 2006). The case study from Xishuangbanna demonstrates an alternative, more positive outcome of the spread of industrial rubber, where government policy enabled local people to transform their lands to rubber production. Smallholders receive the profits from their production and have long-term (30 year) renewable lease rights to their land.

\section{Shifting Rural/Urban Relations and Expanding Urban Labor Markets}

The previous trends have largely entailed either enclosure or nation-states creating management territorialies, or both. These processes have frequently resulted in the dispossession of the swiddeners who once farmed those lands, if they didn't transform them into commercial growers or community foresters. So what happens to the swiddeners who actually lose access to their land or cannot continue to live by swidden agriculture alone or in combination with local off-farm opportunities? Rigg $(2005,2006)$ has published critical work showing that for many rural people, agricultural livelihoods are no longer dominant in much of Southeast Asia, even for people whose primary residences are in rural areas. His case is made primarily for Thailand with strong data from Java and parts of the Philippines. Vandergeest (2003) and Walker (2004) have put forward similar data showing that upland people, especially in Laos and Thailand, are literally losing ground. As markets and physical infrastructures are developed and small-scale manufacturing, processing, transport and services along with them, more and more people are finding wage-labor opportunities in cities, along coasts, in commercial enterprises, and even overseas. Some younger generation people who would have inherited swidden or tree crop plots are choosing to seek other livelihoods in cities, towns, and other sites of production. Some are drawn to opportunities to work overseas, in Taiwan, Hong Kong, or Saudi Arabia. Rigg (2005) presents some significant statistics on this point.

This movement to wage labor coincides closely with the displacement of these people and is part of the larger process of capitalist development of these economies. Though some work has begun on these shifting ruralurban relations, it is the least well understood aspect of the decline of swidden (Vandergeest 2003; Glassman 2006; Nevins and Peluso 2008).

\section{Swidden Landscapes Changed Through Policy Initiatives: Some Examples}

The second half of this article demonstrates in more detail some of the ways political-economic processes, policies, institutions, and practices have changed the former swidden landscapes of Southeast Asia.

\section{Xishuangbanna, Yunnan, China: Industrial Production of Rubber}

Before the 1949 Chinese Revolution, Xishuangbanna was a tiny Southeast Asian principality populated largely by Dai, Akha, Lahu, Jinuo and other groups, all of whom practiced shifting cultivation. Following 1949, Xishuangbanna was incorporated into China, and the Chinese central government introduced rubber there as a strategic industrial product on large-scale state farms. None of the minority people were thought suitable for rubber production. Accordingly, Han Chinese from elsewhere were moved, in different waves of resettlement, to Xishuangbanna to staff the State Rubber Farms. In the mid-1950s, after the Korean War, the Bureau of Reclamation brought in demobilized Han soldiers to clear land for rubber. During the Cultural Revolution, over 100,000 educated youth from cities across China, all of them Han, were sent to work on State Farms in Xishuangbanna (Yunnan Province Bureau of Reclamation 2003; Deng 1993). Limiting rubber production to Han reinforced centuries-old constructs of minority peoples as inferior to the Han.

From the late 1950 s to the early 1980 s, minority farmers in areas not converted to rubber by state farms labored in agricultural communes, where they continued swidden agriculture. In the early 1980s, the government dismantled the communes and distributed agricultural and forest land to these ethnic minority households. At the same time, agricultural land was administered under the Ministry of Agriculture and forest land under the Ministry of Forestry, dividing the landscape into permanent agriculture and forests. A related policy change forced farmers to pay for their own education, health care, and local state services, 
leading many farmers to plant cash crops on available lands. Beginning in the mid-1980s, a series of state campaigns encouraged farmers to plant rubber on their land previously used for shifting cultivation.

In 2003, the incentive for planting rubber became even stronger under a new "Grain for Green" campaign. Grain for Green was an environmental conservation initiative to encourage farmers to plant trees on sloping agricultural land. In Xishuangbanna under Grain for Green, farmers received grain and cash subsidies for planting rubber trees, since rubber is classified as a forest species in China. In 2003, the world rubber price began to rise dramatically, causing farmers to plant even more rubber. As a result, over the past six years minority farmers have planted rubber in household woodlots, village forests, and on remaining sloping land. At elevations of $700 \mathrm{~m}$ and higher, rubber (clonal varieties) has become ubiquitous.

Han resettlement to Xishuangbanna occurred mainly in relation to the state rubber farms mentioned above. The prefecture population is now divided almost equally between Han and an assortment of minority groups. The skyrocketing price of rubber has enabled some rubber farmers to expand their land holdings through new kinds of informal rental and share-cropping arrangements with other villages and even across the border in Laos. While these arrangements do not amount to private property in land (which is still not allowed in China), the speed of acquisition is driven by production relations that approximate capitalism in other ways, and which deserve further research. Interestingly, the state infrastructure that services the industrial state rubber farms in Xishuangbanna now helps subsidize the production and marketing efforts of ethnic minority rubber farmers as well.

\section{Northern Laos: Remaking Forests and Agriculture}

Across the border in Northern Laos a different story unfolded. The region's landscape had been dominated by swidden fields and fallow agroforests in the uplands. These were cultivated by people of Sino-Tibetan, Mon-Khmer and H'mong-Yao ethno-linguistic origins, regarded as political 'minorities', while lowland valleys were occupied by Tai ethno-linguistic groups that based their livelihoods on paddy rice production and trade. The economic and demographic landscape of the region was severely disrupted in the 1960s and 1970s due to the Indochina War. Political insecurity persisted after 1975 until the mid 1980s, as the new socialist government encouraged resettlement of upland 'minorities' to the lowlands to directly suppress political insurgency and to 'modernize' agricultural production. During the 1980s, State Forestry Enterprises and the military utilized forests for commercial timber. The territorial boundaries of these forests, however, remained ambiguous until the late 1980s, when the first national forest inventory was carried out by the Department of Forestry with international assistance. The forest inventory distinguished forests into "scientific" management categories, including conservation, and delineated these areas on official maps.

Throughout the 1990s, the Department of Forestry developed new policies and legislation to promote conservation, imposing restrictions on upland peoples' access to their swidden fields and fallows. Foresters demarcated protected areas under the National Biodiversity Conservation Areas Law of 1993 and Forest Law of 1996, and implemented the National Land and Forest Allocation (LFA) Policy that established village boundaries. Although policies such as LFA recognized villagers' rights to manage and use forest resources as well as some farmers' rights to use land for agriculture, including swidden fields, it placed a significant emphasis on forest conservation by limiting the number of plots allocated to a household, and categorizing most fallow land as different types of conservation forests - thus prohibiting its re-use as agricultural crop land (Fujita and Phanvilay 2008). At the same time, development projects directly and indirectly induced relocations of upland populations during the 1990s by encouraging them to move to so called "focal sites" where the government built basic service infrastructure (Vandergeest 2003, Baird and Shoemaker 2007).

After 2005 upland minorities in northern Laos were further affected by a national campaign to eradicate opium cultivation in swidden fields. The stringent campaign triggered the exodus of many minority people to lower elevations (Cohen 2009). Fujita et al. (2007) documented a $20 \%$ decline in the number of Akha villages in a Lao district bordering China between 1995 and 2005 as villages were forced to relocate and consolidate. The study also showed a decline in the total population in the mountainous regions of the same district by as much as $30 \%$ to $50 \%$ in particular sites. Together with new legal restrictions on swidden agriculture, the strong discouragement of opium cultivation led many swiddeners to seek alternative means of livelihood. Many relocated along the new roads and engaged in commercial agriculture. People lucky enough to gain access to land planted commercial crops, while others worked as agricultural wage-laborers.

Throughout the 1990s, the livelihoods of upland people shifted slowly from subsistence to commercial farming. The government removed agricultural price regulations, production quotas, and agricultural taxes in 1986, allowing farmers to sell their products. As political tensions with neighboring countries eased, the Lao government opened its borders with China and Thailand in 1990, not only increasing the flow of goods but allowing the construction and improvement of roads. In northern Laos increased 
investment from neighboring countries, especially China, followed. These changes opened new economic opportunities for upland farmers, whose livelihoods were already in transition.

Planting cash crops such as sugarcane and rubber allowed farmers with capital (usually pioneer farmers who first experimented with planting these crops) to make more claims to land. Small and medium scale Chinese investors from across the border with family and/or pre-existing social ties initially encouraged and financed local farmers to plant cash-crops in northern Laos (i.e., watermelon, chilies, pumpkin, rice, sugarcane, maize, cassava, rubber etc.). This allowed some local farmers that already had access to productive agricultural land to mobilize labor to intensify land use and produce commercial crops. At the same time, hoping to put a damper on the opium trade through China, the Chinese national government started a program providing loans to Chinese businesses to invest in opium eradication projects in Laos and Myanmar. Under this rubric, increased numbers of new larger Chinese investors supplied Lao farmers with seeds and inputs for commercial production of sugarcane and rubber crops. As a result, competition for swidden and fallow forests intensified, altering not only upland people's customary relationship with land and resources, but challenging the resource management framework established during the 1990s.

Phanvilay (2009) documented the expansion of rubber in an Akha village near the Chinese border. The village developed a Land and Forest Allocation plan in the mid 1990s, which not only distinguished forest and non-forest boundaries, and defined management rules, but also recognized farmers' access to upland swidden and fallow on a customary basis though limiting farmers to three or four plots. Although, this did not grant farmers formal land title to their upland swidden and fallow fields, an informal land market sprang up in the village. Phanvilay observed that pioneer farmers whom were the first to plant rubber capitalized on the more vulnerable economic status of late adopters by informally buying upland fields claimed by them. The village committee responsible for implementing the LFA plan is now under pressure to help poorer households that sold their upland fields to find land for rubber production. Yet, under the village LFA, the majority of the fallow forests are reserved as village conservation forests, meaning that reallocation of land to poor households will require further forest clearing. Moreover, in 2007 the Lao military and a private company jointly planted some 200 ha of rubber within this village's boundaries, thus aggravating the land scarcity problem. This case demonstrates how swidden fields and fallows have been privatized in the process of adopting commercial agriculture by individuals, corporations, officials, and others planting long-term crops such as rubber in the absence of formal land tenure. This not only indicates the loss of customary resource management practices, but a failure of formal resource management institutions to substitute for those practices and secure long-term access to essential assets such as land and natural resources for less well-off farmers.

Northern Thailand: Protected Landscapes and Vulnerable People

In Northern Thailand, national policy makers have been concerned for years about land-use and watershed management practices in the Ping River basin, a major source of water for Central Thailand and Bangkok. In the 1960s and 1970s large areas of the basin were set aside as forest reserves in order to protect forests and watersheds; many of these were subsequently declared national parks and wildlife sanctuaries. In the mid-1980s, a national program was launched to classify all lands in the country according to their watershed characteristics, which, under the guise of science, placed new restrictions on the ability of people to use land for swidden agriculture (Thomas 2005). In addition to constraints on their land-use practices, legally precluding swidden agriculture, people living on these protected lands are not eligible to apply for official land tenure documents. Most people in midland and highland zones of Northern Thailand have no official recognition of their land uses because their land is classified as state forest land, and/or because use is restricted by protected watershed status. Thus land they may have used for decades cannot be used as collateral for credit, is difficult to defend against encroachment by outsiders, and cannot be taxed by local governments.

While at the national level, land use is officially forbidden or heavily restricted in most upland areas, many forms of land use (including limited areas of swidden) are sanctioned and governed by local institutions. Substantial and growing discrepancies exist between what land uses are recognized by government institutions operating at different scales, with more support for forestry on the national scale and more for commercial agriculture at regional and local scales.

Since 1969 the Royal Project Foundation (RPF) has promoted new crops to replace opium in the highlands of Northern Thailand (Thomas et al. 2008). In the early years the RPF solicited wide cooperation from government and non-governmental agencies including foreign donors and technical assistance agencies. Through these partnerships RPF conducted on-farm research in new, alternative crops suitable for the highlands. Most of the crops introduced were temperate, high-value, capital intensive crops, such as vegetables (lettuce, strawberry, Japanese pumpkin, zucchini, 
bell pepper, carrot), flowers (statis, gypsophylla, carnation), and fruits (avocado, peach, pear, apricot, apple).

Thailand finally passed a Community Forest Bill in November 2007, after 18 years of drafts and revisions; the Bill allows people living in forests to participate in forest management and to support government forestry efforts to protect forests. Two provisions in the law (articles 25 and 35 ), however, are viewed by many as depriving communities of their rights to manage forest and to use resources that they have been protecting for generations. These articles exclude from eligibility to community forest rights 20,000 forest-dependent communities living outside protected areas and prohibit even eligible communities from cutting any trees in these forests. Some say the CFB thus deprives rural populations of traditional rights on which their livelihoods depend (Walker 2004). Forest policies, however, have often been implemented in a manner where some illegal land-use practices have been tolerated and in an environment where off-farm employment opportunities have been available. Thus local people's livelihoods have not deteriorated and in many cases have improved significantly.

In addition to the policies that constrain farming in upland watersheds and the citizenship rights of minority peoples, Thailand has strongly pushed economic development policies that are export oriented and emphasize diversification of the economy away from agriculture into industrial and service sectors. Thus, while Thailand remains the largest agricultural economy in the region, the share of agriculture in its overall economy has dropped to very low levels (Thomas et al. 2008). Rigg and Nattapoolwat (2001) suggest that few farmers in Thailand today rely solely on agriculture to meet their needs. Rural households are increasingly dividing their time between farm and nonfarm activities including off-farm employment opportunities.

Sarawak, Malaysia: From Swiddeners to "Joint Venturers"

The territorialization strategies of the Sarawak state have been directed primarily at controlling the expansion of shifting cultivators and reserving forest land for logging and plantations. In the nineteenth century the Brookes (who ruled from 1841 to 1941) were at first merely concerned to prevent the Iban in particular from getting too far away from government control. Ironwood markers were inserted to indicate the upriver boundaries of authorized settlement, but these proved difficult to enforce. By the 1920s and 1930s the Brooke Government was endeavoring to establish permanent forest reserves, following the example of the Malayan Forest Service. A major internal report on Sarawak's administration condemned "our present policy of non-interference" and advocated that "legislation should be introduced to confine the operations of the shifting farmer to secondary forest." In addition, "having classified all forest areas, legislation should then be introduced to prohibit the felling of virgin forest except for permanent forms of agriculture" (Le Gros Clark 1935: 31). Following the report's recommendations, the total area of forest reserves was increased from $1.2 \%$ of Sarawak's land area in 1934 to $5.5 \%$ in 1940 (Cramb 2007).

The post-war British Colonial Government (1946-1963) took sterner action to restrict shifting cultivation, increasing the area under forest reserves to $24 \%$ by 1960 and introducing a total ban on the felling of primary forest for shifting cultivation, effectively from the introduction of the 1958 Land Code (though some local administrative approvals were given to clear primary forest in the 1960s). The Land Code became the hallmark of the colonial legacy in Sarawak. The Code formalized the concept of legal pluralism, loosely adhered to during the Brooke administration, allowing the co-existence of both formal land rights and customary or traditional land tenure. Customary rights were recognized under the Code if such rights could be shown to have been created prior to 1 January 1958. Pre-existing rights could be demonstrated in various ways. Section 5 (2) of the Code states that customary rights were created by felling virgin jungle and occupying the land; planting fruit trees; occupying or cultivating land; using land for burial or to build a shrine; using land for right-of-way; and using land in other lawful methods. Section 5(2) allowed local people to enforce their own customary rules or adat on customary landslands held in common. These rights, however, were limited to farming, harvesting, and gathering, and specifically did not include the right of individual private property in land that could be alienated to whomever. Land could be transferred to others recognized as "natives," a category that excluded Europeans and Chinese. Natives in lawful occupation of customary land were declared as licensees of Crown Land (Porter 1967). In addition, the expansion of swidden agriculture beyond customary territories was curtailed by the Forest Ordinance 1953, reflecting a systematic legislative effort by the post-war colonial government of Sarawak to protect forest land for commercial exploitation.

The Land Code Amendment Bill of 2000, the most important legislative change since independence, deleted the cultural component embodied in Section 5(2) of the Land Code, making the concept of legal pluralism dysfunctional because once culture (which included swiddening as a life style) was detached from the Land Code, native peoples had to provide proof of physical occupation using legal documents, maps, and other instruments; this is problematic today since most of the older or pioneering generations who witnessed pioneering 
practices are gone. The State considers fallowed farmlands to be abandoned land and hence state property. The Land Code Amendment Bill 2000 allowed the state to free large areas of fallow farmlands from customary rights in order to provide land to private sector actors for large-scale oil palm plantations.

During the military confrontation with Indonesia (19631966) and during the 1966-1975 "Emergency", the national government implemented involuntary land resettlement schemes to improve security and protect longhouse communities, which were constantly harassed by insurgents. During this period, a large number of Ibans were relocated in rubber resettlement schemes administered by the Sarawak Land Development Board (Ngidang 1996, 2002). The displacement of people from their traditional swiddens to mono-crop smallholder rubber schemes played an instrumental role in the discontinuance of swiddening.

In the aftermath of the Kuala Lumpur racial riots of 1969, the government introduced the "New Economic Policy" in West Malaysia in 1970. The policy was later extended to the two East Malaysian states, Sarawak and Sabah, with the intent of "domesticating" shifting cultivators through diverse agricultural subsidy schemes. The Department of Agriculture (DOA) provided technical advisory services and both cash and kind incentives to support the adoption of new crops such as rubber, pepper, and cacao. In the 1980s the DOA, with funding from the World Bank, implemented a National Extension Project that accelerated the adoption of new agricultural techniques and crops among farmers throughout Sarawak, intending to further reduce their dependence on swidden agriculture. Later, the DOA supported smallholder oil palm cultivation in selected areas such as Limbang, Niah and Tinjar Districts (Majid-Cooke et al. 2006).

The forced land resettlement schemes eventually failed. These were replaced with in situ farm schemes that were implemented by the Sarawak Land Consolidation and Rehabilitation Authority (SALCRA), established in 1975. These in situ schemes were more favorable to longhouse dwellers because they did not require them to relocate in order to participate. Farmers could maintain their "traditional" lifestyles, including swidden agriculture, hunting and gathering, engaging in off-farm jobs, and growing cash crops like rubber and pepper, in addition to working on the farm scheme. However, these schemes were restricted to southern Sarawak (from Lundu to Saratok), leaving extensive areas for private and joint-venture land development in the rest of the state.

In 1982 another land development agency, the Land Custody and Development Authority (LCDA), established a joint venture concept to promote commercial ventures in the plantation sector. In the $1980 \mathrm{~s}$ joint ventures between landowners and the private sector actors did not materialize because Iban and other Dayak leaders strongly opposed the scheme fearing that poor Dayaks might lose their land in unfavorable deals with private actors. At this time, lucrative timber investment opportunities distracted many investors. By the turn of the century, after more than two decades of political pressure, Iban and other Dayak leaders finally agreed to the "Joint Venture Concept" for developing large tracts of native customary land in Sarawak. Under this concept of land development, native communities are persuaded to surrender their customary lands to the Land Custody and Development Authority (LCDA), which acts as custodian of their land rights. Under the Joint Venture Concept, fragmented native customary lands in a village are consolidated into a "land bank." Once the land bank is surrendered to the LCDA, it is surveyed as a whole and given a master title and leased to the Joint Venture Company for 60 years. The equity in the JV Company is distributed among three partners: $60 \%$ held by the private investor, $30 \%$ by landowners, and $10 \%$ allocated to LCDA. These schemes totally replace swidden fallows with oil palm plantations (Cramb 2007). Unfortunately, this unique land reform, which would purportedly make landowners rich, has disempowered them and empowered the private sector instead; and the economic results to date have been disappointing.

\section{Swidden and the Drivers of Change in Indonesia}

Among Indonesian foresters, and many Dutch foresters before them, especially in the Java-centered Forest Department, swiddening was considered to be "robber farming." To foresters, swiddeners damaged forests, although under colonialism the dipterocarp forests growing on Sumatra and the Indonesian provinces of Borneo known today as Kalimantan were not yet valued for their timber. More important was land control: the infamous 'Domeinverklaring' or 'Domain Declaration', which came into law in Java in 1870 , was aimed at separating out the land under permanent crops from "waste land," the latter a category that included secondary forests and swidden fallows. If land was not cultivated with field crops for a period longer than three years, it was considered "abandoned" by government officials. By colonial agrarian law, such waste lands could be resumed by the state and re-allocated to European plantation enterprises under long lease. The accompanying law banning swidden was passed for Java in 1874. In general, the blame for upland forest loss was attributed entirely to swidden cultivation and a force of forest police was dedicated to eliminating it in Java.

Neither the Domain Declaration nor any restriction on swidden was applied immediately to the Outer Islands, but came into force at varying times. It was introduced 
into South and East Borneo in 1888 so that tobacco and other plantations could be tried. Because there was not yet much of a formally reserved "political forest" in Kalimantan, the main "problem" with swidden from a state point of view was its potential interference with commercial agriculture.

Swiddeners were not stigmatized until the authoritarian and Java-centric rule of second President Suharto (19661998). While the Suharto government represented many peoples in the archipelago as culturally inferior, special opprobrium was reserved for those described as suku-suku terasing or "isolated tribes." Such people were usually animists, living in remote localities, and either swiddeners or hunter-gatherers. Larger national minorities, such as many of the Dayak groups in West Kalimantan, were Christian, but government officials and official discourse still treated them as backward.

As in Dutch times, swiddening was mainly criticized because of its extensive nature. Under Suharto, the government, through its 1967 Forestry Regulation and later reinforced by its forest land-use categories (production forest, protection forest, parks and reserves), claimed large portions of Indonesia's land for forests and forest plantations. Production forest land was leased to corporations for logging and timber or pulp plantations. Plantations, such as rubber, cocoa, or oil palm, and settlements of transmigrants and others were restricted to "conversion forests" or lands under "other uses," both of which also included swiddens.

Land-use categories did not consider pre-existing settlements. The World Bank (2007) estimated that 5060 million people lived in 'forest' areas. During the Suharto era, attempts were made to evict people from both protection forests and national parks, while villages falling within production forest were pressured to give up swiddening. The project described briefly below, to convert remote villages from swidden to wet rice cultivation was typical of the 1990s. Most such "conversions" received temporary financial assistance with the inevitable result that the conversion failed after the assistance was withdrawn.

Following the fall of Suharto in 1998 and decentralization in 2001, less restrictive policies have gradually been applied, although secure tenure, in the form of long leases, has only recently become available for villagers in production forests, provided they plant trees (Law 6 of 2007). The production forest/convertible forest boundary has always been contested, especially as many "production forests" no longer have tree cover. Such lands have sometimes been reclassified by the Minister of Forestry to allow oil palm production, while decentralized districts have included them as "agricultural" in their own land-use plans. In provinces such as Central Kalimantan, where there was little convertible forest on initial maps, large areas have now been released from the "forest" category to make way for oil palm.

In West Kalimantan, land along the Kapuas River is classified as "other uses," which means that it has long been recognized as agricultural. In this area, where the oil palm industry in Kalimantan began in 1975, companies seeking land for plantations must negotiate with Dayak villagers. Villagers manage complex agroforestry systems of communal fruit gardens and rubber groves, often with communal forest, wet and dry swiddens, and occasionally irrigated wet rice. In Central Kalimantan, on the other hand, where population pressure is lower, plantations have often gained direct access to degraded forests and negotiations between plantations and local people have been slow to develop. Even now, many estates rely on Javanese transmigrants or contract laborers to provide their workers. Central Kalimantan has recently eclipsed West Kalimantan as the leading oil palm grower in Kalimantan. ${ }^{1}$

The two case studies described below form an interesting contrast. Oil palm development is not expected in the near future in remote Tanjung Paku, Central Kalimantan, far to the north of the oil palm belt, where swiddening is an appropriate form of agriculture and likely to continue, despite official disapproval. In the Sanggau area, in West Kalimantan, oil palm plantations are extensive and farmers struggle to find compromises between their swiddening tradition and the new commercial systems.

Farmers in Tanjung Paku, a village located in Central Kalimantan near the West Kalimantan border, practiced swidden agriculture within a production forest until a timber concession arrived in 1990. Under the government's Village Forestry Development program, the timber concession launched programs to extend irrigated rice fields, tree plantations, fish ponds, and vegetable gardens to the village. With new opportunities to earn cash income, farmers slowly left their traditional swidden systems, and gradually reduced the size of their plots. At first the fact that farmers cleared less land for swidden meant that the amount of land in forest fallow increased. Unfortunately, however, the program only worked as long as the timber concession provided farmers with subsidies to grow irrigated rice, using expensive fertilizer and other inputs. After the subsidy was reduced farmers reversed the process, began to leave their irrigated rice fields, and move back into traditional swiddening. In 2004, about 59 out of 95 households practiced shifting cultivation in secondary forests.

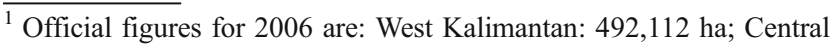
Kalimantan 571,874 ha; South Kalimantan 243,451 ha and East Kalimantan 237,765 ha (Direktorat Jenderal Perkebunan (2007) Jakarta). Areas under the crop expanded further in 2007-2008 as a result of high prices, but these have fallen since November 2008.
} 
Sanggau District in West Kalimantan is the birthplace of oil palm in Kalimantan. In 1975 the Governor suggested oil palm plantations be introduced to utilize 'sleeping' swidden fallows especially where Imperata grass or erosion were visible (Perusahaan Negara Perkebunan VII 1984:15). In 1979, a Sumatra-based government plantation company started the Sanggau Project on the Kapuas River by bulldozing Dayak rubber gardens and tembawang (fruit) groves. Labor was partly local, mainly transmigrant, but there were initially no smallholders. In 1982, the World Bank financed a 'nucleus estate and smallholder scheme in which an estate core, surrounded by mainly local smallholders, was established. Potter and Lee (1998:25) discovered that Dayak smallholders were still actively maintaining their swiddens and rubber gardens and diverting fertilizer from the oil palm (which had declined in production) to their rice fields. By making their swidden field their main priority, farmers sacrificed higher oil palm yields to the need for subsistence rice and social demands for rice wine. Oil palm had become just another element in their extensive livelihood system.

During the 1990s private companies began setting up oil palm estates in the district. PT Sime Indo Agro (SIA) (owned by the Malaysian conglomerate Sime Darby Berhad) asked farmers to provide 7.5 ha of land: 5 for the estate, 2 to be returned to the farmer planted in oil palm, and 0.5 ha for infrastructure. Communities were initially reluctant but they were pressured by government officers and village headmen, all rumored to have received payments from the company. Although they possessed assets in the form of reasonably large landholdings, averaging 15 ha, under the new arrangements farmers' access to land, especially swidden land, was considerably reduced.

In 2002 Potter and Badcock studied five hamlets (dusun) targeted by PT SIA and Potter briefly re-visited the area in February 2007. In 2002, prior to the release of their smallholdings, farmers worked as estate laborers. Rubber prices were low and farmers were willing to convert old rubber land into oil palm; they also appreciated the wages paid by PT SIA. However, they continued to grow upland rice and they also wanted to preserve their communal fruit orchards (tembawang) (Potter and Badcock 2007).

In one hamlet villagers readily allotted half their land, covered in Imperata grass, to oil palm on which they worked communally. They were able to retain the rest of their land under traditional management, including swiddens and a communal forest. A strong customary (adat) chief refused to allow the tembawangs to be cleared. In a second hamlet the headman enthusiastically embraced oil palm; with the exception of four families, other villagers joined him in this venture. However, the price was unexpectedly high as rats from the newly cleared fields decimated rice crops and yields decreased every year. Although it was no longer economical to plant rice, people continued to do so for cultural reasons. By 2007 the rat problem had abated and villagers were again able to harvest their sticky rice (padi pulut) for rice wine, an important indicator of wealth and status, although they were no longer self-sufficient in food. All participating households worked through a cooperative that recorded the amounts of land contributed. In 2002 only $30 \%$ could provide the full 7.5 ha to the company.

Farmers in these hamlets are designing, by intention or default, a modified multi-cropping system with oil palm largely replacing traditional 'jungle' rubber, but with some upland rice and areas of tembawang being allowed to remain. Although there were complaints about PT SIA's initial acquisition of village land, many now see oil palm as a useful contributor to the local economy. While the idea of the swidden still resonates as a symbol of Dayak identity, an idea strongly held by some traditional leaders and local NGOs (Petebang and Bider 2001), sufficient land for large swidden fields no longer exists.

\section{Conclusions}

For centuries, swidden cultivation was an important farming practice found across the girth of Southeast Asia. Today, however, these systems are changing and sometimes disappearing at a pace never before experienced. Swiddening has always been characterized by change, but since the onset of modern independent nation states, government policy and the expansion of capitalism in new forms have transformed the landscape and swidden practices through mechanisms that are different in the extent and depth of their landscape effects than ever before. In this paper we identified six causes of the demise and transformation of swidden systems, and augmented this general argument with examples from across the region.

Some of the struggles between lowland and upland groups and their conflicts over upland resources have been aggravated with the construction of nation-states and the resultant change in the status of upland groups as ethnic minorities, in relation to nation-state political configurations. As minorities, many swiddeners' land and resource management practices are misunderstood. Some are thus denied ownership and land-use rights.

Second, swiddening has been ill served by the division of the landscape into forest and agricultural sectors. Swiddening is an extensive agroforestry system; a coherent system of land use that has been falsely split between forest and agricultural jurisdictions. In part this divided management authority between forest and agricultural departments derives from understandings of agriculture more suited to lowland areas and temperate climates. 
Claims to land by forestry departments and the transfer of ownership and land-use rights to logging companies and commercial plantations have prompted major changes, usually detrimental to the practice of swiddening with its difficult-to-categorize fallows.

The expansion of forest departments and the rise of conservation have further affected national policies on swidden. In terms of territory, postcolonial Southeast Asian states have reserved or gazetted more territory as forest since their inception than at any time before in history. Forestry departments have become crucial and powerful, well-funded players in state bureaucracies. The rise of international corporate conservation after 1980 further cemented state legal controls over forests; in policy at least created new state and international controls on forests for conservation and nature preservation.

Swiddeners have also been resettled out of upland areas and away from forests and borders, displaced and dispossessed of their lands by state land expropriation. This can occur over a period of years sometimes and at others it has occurred quickly and coercively. The fact remains, however, that neither their territorial claims as groups, where these are still extant, nor their individual and extended family land rights, are recognized or compensated fairly by the governments moving them.

These instances of state territorialization and zoning of land out of the legal reach of swiddeners have been accompanied by new forms of capitalist land and resource enclosure. Capitalist markets and practices have extended into Vietnam, Laos, and China, and taken new forms, leading to major dispossessions of swiddeners as in Indonesia, Malaysia, and Thailand. The marginalization of swiddeners has been affected by the extension of capitalist relations and changes in capitalism itself that have driven the privatization of land and the rise of mono-cultural commodity production, both by small or medium landholders and corporate plantations growing agricultural or forest tree crops. Modern nation states have purposely established and implemented national laws and policies that recognize and enforce Western-style, state-authorized, private property rights at the expense of communal or other traditional systems. These laws affect the ways private ownership is recognized and allow state authority to supersede local authority and communal management of natural resources.

Commoditization of the landscape and its products has led to further expansion of infrastructure and labor markets for on and off-farm work, accelerating the demise of swidden agriculture. Across the region state policies have driven the expansion and upgrading of road, electricity, and telecommunication networks, factors critical for enabling the emergence of market production opportunities. The major commodities including oil palm, rubber, tea, and coffee now occupy a large percentage of the national land base in many countries, produced in industrial agricultural estates.
National policies and global processes over the last half century have thus significantly affected the practice of swidden agriculture across Southeast Asia. Most swiddeners were formerly peripheral to state power and represented by national decision makers as "backward" people over whom states needed to exert control. Their lands and many of these previously remote areas are now sites of exchange, commerce, and trade, not to mention subject to new property rights. We are seeing a partial but important shift from directed and even coerced land-use change to drive larger social and political projects, to land-use change now being driven by larger political-economic forces. These new opportunities are overlaid on a physical, social and political landscape shaped by 50 years of intensive state building, development and expansion across the region. The end result of all these changes is that the conditions necessary for swiddening, both the availability of land and the aspirations of people, simply no longer exist in many parts of Southeast Asia. The traditional agrarian question about the impact of capitalism on agriculture is thus alive and well in the uplands and other parts of Southeast Asia where swidden agriculture was or still is being carried out. This article has made a modest attempt to begin unpacking the roles of policies and political economic change in these agrarian transformations.

Open Access This article is distributed under the terms of the Creative Commons Attribution Noncommercial License which permits any noncommercial use, distribution, and reproduction in any medium, provided the original author(s) and source are credited.

\section{References}

Abdullah, O. (1996). Social and environmental impacts of transmigration: A case-study in Barambai, South Kalimantan. In Padoch, C. and Peluso, N. (Eds.) Borneo in Transition: People, Forests, Conservation, and Development. Oxford University Press, Kuala Lumpur.

Anderson, B. (1991). Imagined Communities: Reflections on the Origin and Spread of Nationalism. Verso, London.

Agrawal, A., and Sivaramakrishnan, K. (2001). Agrarian Environments: Resources, Representations, and Rule in India. Duke University Press, Raleigh.

Baird, I. G., and Shoemaker, B. (2007). Unsettling Experiences: Internal Resettlement and International Aid Agencies in Laos. Development and Change 38: 5865-888. doi:10.1111/j.14677660.2007.00437.x.

Barber, C. V., and Churchill, G. (1987). Land Policy in Irian Jaya: Issues and Strategies. Jakarta: GOI-UNDP/IBRD. Government of Indonesia, United Nations Development Program, and International Bank for Reconstruction and Development, Jakarta.

Belsky, J. M. (2008). Creating community forests. In Donohue, E. and Sturtevant, V. (Eds.) Forest Community Connections: Continuity and Change. Resources for the Future, Washington, DC.

Boomgaard, P. (2005). The long goodbye? Trends in forest exploitation in the Indonesian Archipelago, 1600-2000. In Boomgaard, P., Henley, D. and Osseweijer, M. (Eds.) Muddied Waters: Historical 
and Contemporary Perspectives on Management of Forests and Fisheries in Island Southeast Asia. KITLV, Leiden.

Brookfield, H., Potter, L., and Byron, Y. (1995). In Place of the Forest: Environmental and Socio-Economic Transformation in Borneo and the Eastern Malay Peninsula. United Nations University Press, Tokyo.

Brown, D. (2003). Addicted to Rent: Corporate and Spatial Distribution of Forest Resources in Indonesia: Implications for Forest Sustainability and Government Policy. UK Tropical Forest Management Program, Jakarta.

Butterfield, R. (1997). Land-Use Allocations and Community Livelihoods: Policy Issues. Associates in Rural Development, Forest Policy Reform Process Project, Phnom Penh.

Chokkalingam, U., Kurniawan, I., and Ruchiat, Y. (2005). Fire, Livelihoods, and Environmental Change in the Middle Mahakam peatlands, East Kalimantan. Ecology and Society 10: 126[online] URL: http://www.ecologyandsociety.org/vol10/iss1/art26/.

Cohen, P. T. (2009). The post-opium scenario and rubber in northern Laos: Alternative Western and Chinese models of development. International Journal of Drug Policy (in press) [online] URL: http:// www.journals.elsevierhealth.com/periodicals/drupol/impress.

Colchester, M., Jiwan, N., Andiko, M., Sirait, A. Y., Firdaus, A., Surambo, A., and Pane, H. (2006). Promised Land: Palm Oil and Land Acquisition in Indonesia: Implications for Local Communities and Indigenous Peoples, Moreton-in-Marsh, England: Forest Peoples' Programme. Perkumpulan Sawit Watch, Bogor.

Cramb, R. (2007). Land and Longhouse: Agrarian Transformations in the Uplands of Sarawak. Nias, Copenhagen.

Cramb, R. A., Colfer, C. J. P., Dressler, W., Laungaramsri, P., Le, Q. T., Mulyoutami, E., Peluso, N. L., and Wadley, R. (2009). Swidden transformations and rural livelihoods in Southeast Asia. Human Ecology. Vol. 3 xx-xx.

Cribb, R. (1997). Birds of Paradise and environmental policies in colonial Indonesia, 1890-1931. In Boomgaard, P., Colombijn, F. and Henley, D. (Eds.), Paper Landscapes: Explorations in the Environmental History of Indonesia. KITLV, Leiden.

Dauvergne, P. (1997). Shadows in the Forest: Japan and the Politics of Timber in Southeast Asia. MIT, Cambridge, MA.

De Haan, J. (1929). Memorie van Overhave, Zuider en Ooster Afdeeling van Borneo (Handing-over Memorial, Southern and Eastern Divisions of Borneo). Unpublished typescript, $\mathrm{MvO}$ No 275, Algemeen Rijksarchief (National Archives), Den Haag, The Netherlands.

Deng, X. (1993). Zhongguo Zhiqing Meng (The dream of China's educated youth). People's Literature, Beijing (in Chinese).

Dennis, R. A., and Colfer, C. P. (2006). Impacts of Land Use and Fire on the Loss and Degradation of Lowland Forest in 1983-2000 in East Kutai District, East Kalimantan, Indonesia. Singapore Journal of Tropical Geography 27: 130-48. doi:10.1111/j.14679493.2006.00238.x.

Dennis, R., Mayer, J., Applegate, G., Chokkalingam, U., Colfer, C., Kurniawan, I., Lachowski, H., Maus, P., Permana, R., Ruchiat, Y., Stolle, F., Suyanto, and Tomich, T. (2005). Fire, People and Pixels: Linking Social Science and Remote Sensing to Understand Underlying Causes and Impacts of Fires in Indonesia. Human Ecology 33: 4465-504. doi:10.1007/s10745-005-5156-z.

Denton, R. K. (1997). Malaysia and the "Original People": A Case Study of the Impact of Development on Indigenous Peoples. Allyn and Bacon, Boston.

Direcktorat Jenderal Perkebunan (2007). Statistik Perkebunan Indonesia. Tree Crop Estate Statistics of Indonesia 2006-2008. Kelapa Sawit (Oil Palm), Jakarta.

Dove, M. R. (1983). Theories of Swidden Agriculture and the Political Economy of Ignorance. Agroforestry Systems, 1: 185-99. doi:10.1007/BF00596351.
Dove, M. R. (1988). The Real and Imagined Role of Culture in Development. University of Hawaii Press, Honolulu.

Elmhirst, R. (1999). Space, identity politics and resource control in Indonesia's transmigration programme. Political Geography 18: 7813-835. doi:10.1016/S0962-6298(99)00029-3.

Fox, J. (2000). How blaming 'slash and burn' farmers is deforesting mainland Southeast Asia. East-West Center Asia Pacific Issues Paper No. 47. Honolulu, HI.

Fujita, Y., and Phanvilay, K. (2008). Land and Forest Allocation in Lao People's Democratic Republic: Comparison of Case Studies from Community-Based Natural Resource Management Research. Society and Natural Resources 21: 2120-133. doi:10.1080/08941920701681490.

Fujita, Y., Thongmanivong, S., Vongvisouk, T., Phanvilay, K., Chanthavong, H. (2007). Dynamic Land-Use Change in Sing District, Luang Namtha Province, Lao PDR. Unpublished report for International Program for Research on the Interactions between Population, Development, and the Environment (PRIPODE). Faculty of Forestry, National University of Laos, Vientiane.

Glassman, J. (2006). Primitive Accumulation: Accumulation by Dispossession, Accumulation by Extra-economic Means. Progress in Human Geography 30: 5608-25. doi:10.1177/ 0309132506070172.

Grinspoon, L. (2002). Socialist Wasteland Auctions: Privatizing Collective Forest Land in China's Economic Transition. Environmental, Science, and Policy and Management Ph.D. dissertation, University of California, Berkeley.

Grove, R. (1995). Green Imperialism: Colonial Expansion, Tropical Island Edens and the Origins of Environmentalism, 1600-1860. Cambridge University Press, Cambridge.

Hardy, A. (2003). Red Hills: Migrants and the State in Vietnam. University of Hawaii Press, Honolulu.

Harvey, D. (2003). The New Imperialism. Oxford University Press, Oxford.

Hidayati, D. (1994). Striving to reach Heaven's Gate: Javanese adaptations to swamp and upland environments in Kalimantan. $\mathrm{Ph} . \mathrm{D}$. thesis in Geography, the Australian National University, Canberra.

Jamieson, N. L. (1991). Culture and Development in Vietnam. Honolulu (HI): East-West Center Working Papers Indochina Series No. 1. East-West Center, Honolulu, HI.

Le Gros Clark, C. D. (1935). The Blue Report. Sarawak Government Printer, Kuching.

Li, T. M. (1999). Marginality, power and production: analyzing upland transformations. In Li, T. M. (Ed.) Transforming the Indonesian Uplands: Marginality, Power and Production. Harwood Academic, Amsterdam.

Li, T. M. (2007). The Will to Improve: Governmentality, Development, and the Practice of Politics. Duke University Press, Durham.

Liam, J. (2005). Local Participation in Managing Natural Resources Conservation in Loagan Bunut National Park. Unpublished Thesis Submitted to the Center of Graduate Studies in Partial Fulfillment of the Requirements for the Degree of Master of Environmental Science (Development Planning), Universiti Malaysia Sarawak, Kota Samarahan.

Long, C., Fox, J., Lu, X., Gao, L., Cai, K., and Wang, J. (1999). State Policies, Markets, Land-Use Practices, and Common Property: Fifty Years of Change in Yunnan, China. Mountain Research and Development 19: 2133-139. doi:10.2307/3674254.

Majid-Cooke, F. (2003). Maps and Counter Maps: Globalised Imaginings and Local Realities of Sarawak's Plantation Agriculture. Journal of Southeast Asian Studies 34: 265-284.

Majid-Cooke, F. (2006). Expanding state spaces using "idle" native customary land in Sarawak' In Majid-Cooke, F. (ed.) State, Communities and Forest in Contemporary Borneo. Asia-Pacific Environment Monograph 1. ANU E, Canberra. pp. 25-44. 
Majid-Cooke, F., Ngidang, D., and Selamat, N. (2006). In-situ offfarm work: Social Transformation of Small-holder Oil Palm Economies of Sabah and Sarawak. Research Project no. 272132 03MAL funded by UNESCO.

Manning, C. (1971). The Timber Boom in East Kalimantan. Bulletin of Indonesian Economic Studies 7: 30-61. doi:10.1080/ 00074917112331331902.

McCarthy, J. (2006). The Fourth Circle: A Political Ecology of Sumatra's Rainforest Frontier. Stanford University Press, Stanford.

Menzies, N. (1994). Forest and Land Management in Imperial China. Palgrave Macmillan, New York.

Moniaga, S. (1993). Toward community-based forestry and recognition of adat property rights in the Outer Islands of Indonesia. In Fox, J. (Ed). Legal Frameworks for Forest Management in Asia: Case Studies of Community State Relations. Program on Environment Occasional Paper No. 16. East-West Center, Honolulu, HI.

Nevins, J. and Peluso, N. L. (Eds.). (2008). Taking Southeast Asia to Market: Commodities, People and Nature in a Neoliberal Age. Cornell University Press, Ithaca.

Ngidang, D. (1996). Batang Ai hydropower resettlement scheme. In Solhee, H., Chew, D. and Sim, A. H. (eds.) Resettlement and Development in Sarawak: Experiences and Future Trends, AZAM, Kuching, pp. 18-32.

Ngidang, D. (1997). Native Customary Land Rights, Public Policy, Land Reform and Plantation Development in Sarawak. Borneo Review 8: 163-80.

Ngidang, D. (2002). Contradiction in Land Development Schemes: The Case of Joint Ventures in Sarawak, Malaysia. Asia Pacific Viewpoint 43: 2157-180. doi:10.1111/1467-8373.00171.

Ngidang, D. (2005). Deconstruction and Reconstruction of Native Customary Land Tenure in Sarawak. Southeast Asian Studies 43: 47-75.

Obidzinski, K., Andrianto, A., and Wijaya, C. (2007). Cross-border Timber Trade in Indonesia: Critical or Overstated Problem? Forest Governance Lessons from Kalimantan. International Forestry Review 9: 1526-535. doi:10.1505/ifor.9.1.526.

Osborne, M. (1965). Strategic Hamlets in South Vietnam: A Survey and a Comparison. Cornell Southeast Asia Program, Ithaca, NY.

Padoch, C., Coffey, K., Mertz, O., Leisz, S., Fox, J., and Wadley, R. (2007). The Demise of Swidden in Southeast Asia? Local Realities and Regional Ambiguities. Danish Journal of Geography 107: (1)29-42.

Peluso, N. L. (1992). Rich Forests, Poor People: Resource Control and Resistance in Java. University of California Press, Berkeley.

Peluso, N. L. (1993). Coercing Conservation: The Politics of State Resource Control. Global Environmental Change, 3: 2199-217. doi:10.1016/0959-3780(93)90006-7.

Peluso, N. L., and Vandergeest, P. (2001). Genealogies of the Political Forest and Customary Rights in Indonesia, Malaysia, and Thailand. The Journal of Asian Studies 60: 3761-812. doi:10.2307/2700109.

Peluso, N. L., and Vandergeest, P. (2009). Taking the Forest out of the Jungle: Counter-insurgency and the Political Forest in Southeast Asia. In Hecht, S., Padoch, C. (Eds). The Social Lives of Forests. University of Chicago Press, Chicago.

Perusahaan Negara Perkebunan VII. (1984). Pertama di Kalimantan Barat: Pabrik Kelapa Sawit Gunung Meliau (First in West Kalimantan: Gunung Meliau Palm Oil Mill). Jakarta: Proyek Pengembangunan Kelapa Sawit di Kalimantan Barat (Oil Palm Plantation Development in West Kalimantan).

Petebang, E., and Bider, B. (2001). Ladang hilang, Dayak pun hilang: masih pantaskah disebut Dayak? (The swidden disappears, so the Dayak disappears: can they reasonably still be called Dayaks?). Kalimantan Review 67: (10)26-27.

Phanvilay, K. (2009). Impacts of land-use and land-cover transitions on people's livelihoods in the uplands of Northern Laos: Case Studies from Bokeo and Luang Namtha Provinces. Ph.D. dissertation, Department of Geography, University of Hawaii.
Poffenberger, M. (Ed.). (1990). Keepers of the Forest: Land Management Alternatives in Southeast Asia. Kumarian, West Hartford, Ct.

Porter, A. F. (1967). Land Administration in Sarawak. Government Printing, Kuching.

Potter, L. (2003). Forests versus agriculture: Colonial forest services, environmental ideas and the regulation of land-use change in Southeast Asia. In Tuck-Po, L., de Jong, W., and Ken-ichi, A. (Eds.) Political Ecology of Tropical Forests in Southeast Asia. Kyoto University Press, Kyoto.

Potter, L., and Badcock, S. (2004). Tree Crop Smallholders, Capitalism and Adat: Studies in Riau Province, Indonesia. Asia Pacific Viewpoint, 45: 3341-356. doi:10.1111/j.1467-8373.2004.00245.x.

Potter, L. and Badcock, S. (2007). Can Indonesia's complex agroforests survive globalization and decentralization? Sanggau District, West Kalimantan. In Connell, J. and Waddell, E. (Eds.) Environment, Development and Change in Rural Asia-Pacific: Between Local and Global. Rutledge, London.

Potter, L., and Lee, J. (1998). Tree Planting in Indonesia: Trends, Impacts and Directions.. Occasional Paper No 18. Center for International Forestry Research (CIFOR), Bogor.

Potter, L., Brookfield, H., and Byron, Y. (1995). In Place of the Forest: Environmental and Socioeconomic Transformation in Borneo and the Eastern Malay Peninsula. United Nations University Press, Tokyo.

Rambo, A. T. (1995). Defining highland development challenges in Vietnam: some themes and issues emerging from the conference. In Rambo, A. T., Reed, R., Le Trong Cuc, DiGregoiro, M. (Eds.) The Challenges of Highland Development in Vietnam. East-West Center, Honolulu (HI), pp. xi-xxvii.

Rich, B. (1995). Mortgaging the Earth: The World Bank, Environmental Impoverishment, and the Crisis of Development. Beacon, Boston, MA.

Rigg, J. (2003). Southeast Asia: The Human Landscape of Modernization and Development. Routledge, London.

Rigg, J. (2005). Poverty and Livelihoods after Full-Time Farming: A South-East Asian View. Asia Pacific Viewpoint, 46: 2173-184. doi:10.1111/j.1467-8373.2005.00266.x.

Rigg, J. (2006). Land, Farming, Livelihoods, and Poverty: Rethinking the Links in the Rural South. World Development, 34: 1180-202. doi:10.1016/j.worlddev.2005.07.015.

Rigg, J., and Nattapoolwat, S. (2001). Embracing the Global in Thailand: Activism and Pragmatism in an Era of Deagrarianisation. World Development, 29: 6945-960. doi:10.1016/S0305750X(01)00021-3.

Ross, M. L. (2001). Timber Booms and Institutional Breakdown in Southeast Asia. Cambridge University Press, New York.

Scott, J. C. (1976). The Moral Economy of the Peasant: Rebellion and Subsistence in Southeast Asia. Yale University Press, New Haven.

Scott, J. C. (1998). Seeing Like a State: How Certain Schemes to Improve the Human Condition Have Failed. Yale University Press, New Haven, CT.

Sioh, M. (2004). An Ecology of Postcoloniality: Disciplining Nature and Society in Malaya, 1984-1957. Journal of Historical Geography, 30: 729-746. doi:10.1016/j.jhg.2003.08.024.

Sturgeon, J. C. (2005). Border Landscapes: The Politics of Akha Land Use in China and Thailand. University of Washington Press, Seattle.

Thapa, G., and Weber, K. (1991). Soil Erosion in Developing Countries: A Politico Economic Explanation. Environmental Management 15: 4461-473. doi:10.1007/BF02394737.

Thiesenhausen, W. (1991). Implications of the Rural Land Tenure System for the Environmental Debate: Three Scenarios. Journal of Developing Areas 24: 11-24.

Thomas, D. (2005). Developing Watershed Management Organizations in Pilot Sub-basins of the Ping River Basin. Office of Natural Resources and Environmental Policy and Planning, Ministry of Natural Resources and Environment, Bangkok 288 p. 
Thomas, D., Ekasingh, B., Ekasingh, M., Lebel, L., Ha, H., Ediger, L., Thongmanivong, S., Xu, J., Sangchyoswat, C., and Nyberg, Y. (2008). Comparative Assessment of Resource and Market Access of the Poor in Upland Zones of the Greater Mekong Region. World Agroforestry Center, Chiang Mai, p. 350.

Thongchai, W. (1994). Siam Mapped. University of Hawaii Press, Honolulu.

Thongmanivong, S., Fujita, Y., and Fox, J. (2005). Resource Use Dynamics and Land-Cover Change in Ang Nhai Village and Phou Phanang National Reserve Forest, Lao PDR. Environmental Management 36: 3382-393. doi:10.1007/s00267-003-0291-z.

Tsing, A. (1993). In the Realm of the Diamond Queen. Princeton University Press, Princeton.

Tsing, A. L. (1999). Becoming a tribal elder, and other green development fantasies. In $\mathrm{Li}, \mathrm{T}$. M. (Ed.) Transforming the Indonesian Uplands. Routledge, London.

Uhlig, H. (1984). Spontaneous and Planned Land Settlement in Southeast Asia. Institute of Asian Affairs, Giesssener Geographische Schriften, Hamburg, p. 58.

Vandergeest, P. (2003). Land to Some Tillers: Development-Induced Displacement in Laos. International Social Science Journal 175: 47-56. doi:10.1111/1468-2451.5501005.

Vandergeest, P., and Peluso, N. L. (2006). Empires of Forestry: Professional Forestry and State Power in Southeast Asia, Part 2. Environment and History 12: 4359-393. doi:10.3197/096734006779093640.

van Noordwijk, M., Mulyoutami, E., Sakuntaladewi, N., and Agus, F. (2008). Swiddens in Transition: Shifted Perceptions on Shifting Cultivators in Indonesia. World Agroforestry Center, Bogor.
Vargas, D. (1985). The Interface of Customary and National Land Law in East Kalimantan, Indonesia. Ph.D. dissertation, Yale University.

Wadley, R. (2003). Lines in the Forest: Internal Territorialization and Local Accommodation in West Kalimantan, Indonesia (18651979). South East Asia Research, 11: (1)91-112.

Wadley, R. L., and Eilenberg, M. (2005). Autonomy, Identity and 'Illegal' Logging in the Borderlands of West Kalimantan, Indonesia. The Asia Pacific Journal of Anthropology, 6: 119-34. doi:10.1080/14442210500074853.

Walker, A. (2004). Seeing Farmers for the Trees: Community Forestry and the Arborealisation of Agriculture in Northern Thailand. Asia Pacific Viewpoint, 45: 3311-324. doi:10.1111/ j.1467-8373.2004.00250.x.

Wolf, E. (1982). Europe and the People without History. University of California Press, Berkeley and Los Angeles.

World Bank (2007). Sustaining Indonesia's Forests: Strategy for the World Bank, 2006-2009. World Bank Office, Jakarta.

Xu, J., Fox, J., Zhang, P., Fu, Y., Yang, L., Qian, J., Leisz, S., and Vogler, J. (2005). Fall Land-Use/Land-Cover Change and Farmer Vulnerability in Xishuangbanna. Environmental Management 36: 3404-413. doi:10.1007/s00267-003-0289-6.

Yunnan Province Bureau of Reclamation. (2003). DVD in commemoration of the 50th anniversary of the establishment of the first state farm in Xishuangbanna.

Zaman, M. (2002). Resettlement and Development in Indonesia. Journal of Contemporary Asia 32: 2255-237. doi:10.1080/ 00472330280000161. 